\title{
Localization of primordial germ cells or their precursors in stage $X$ blastoderm of chickens and their ability to differentiate into functional gametes in opposite-sex recipient gonads
}

\author{
M. Naito ${ }^{1}$, A. Sano ${ }^{1}$, Y. Matsubara ${ }^{1}$, T. Harumi ${ }^{1}$, T. Tagami ${ }^{1}$, \\ M. Sakurai ${ }^{2}$ and T. Kuwana ${ }^{3}$ \\ ${ }^{1}$ Genetic Engineering Laboratory, National Institute of Animal Industry, Tsukuba \\ Norindanchi PO Box 5, Ibaraki 305-0901, Japan; ${ }^{2}$ National Institute of Animal Health, 3-1-1 \\ Kannondai, Tsukuba, Ibaraki 305-0856, Japan; and ${ }^{3}$ Pathology Section, National Institute for \\ Minamata Disease, Minamata, Kumamoto 867-0008, Japan
}

This study was performed to determine the distribution of primordial germ cells and their precursors in stage $X$ blastoderm of chickens. The blastoderm (Barred Plymouth Rock chickens) isolated from the yolk was separated into three portions: the central disc, the marginal zone and the area opaca. The dissociated blastodermal cells derived from the central disc, marginal zone and area opaca were transferred into a recipient blastoderm (White Leghorn chicken) from which a cell cluster was removed from the centre of the central disc. The manipulated embryos were cultured in host eggshells until hatching. The chicks were raised until sexual maturity and test mated with Barred Plymouth Rock chickens to assess the donor cell contribution to the recipient germline. Germline chimaeric chickens were produced efficiently $(46.7 \%, 7 / 15)$ when the blasto- dermal cells derived from the central disc were transferred into recipient embryos of the same sex, whereas no germline chimaeric chickens were produced when the blastodermal cells derived from the marginal zone or area opaca were transferred into recipient embryos of the same sex (0/12). Germline chimaeric chickens were also produced by transfer of blastodermal cells derived from the central disc $(6.7 \%, 1 / 15)$, marginal zone $(10.0 \%$, $1 / 10)$ or area opaca $(11.1 \%, 1 / 9)$ into recipient embryos of the opposite sex. It is concluded that primordial germ cells are induced during or shortly after stage $X$ and that the cells derived from the central disc have the highest potential to give rise to germ cells. Cells derived from the marginal zone and area opaca can also give rise to germ cells, although the frequency is low.

\section{Introduction}

Germline segregation in chickens starts at a very early embryonic stage and they first appear as primordial germ cells. Manipulation of primordial germ cells is very useful for producing transgenic chickens and also for preserving genetic material in avian species (Naito, 1997, 1998; Naito et al., 1991a, 1994a,b, 1998a, 2000a,b; Tajima et al., 1998; Wentworth et al., 1996; Wong et al., 1999), as primordial germ cells are progenitor cells of ova and spermatozoa, and manipulated primordial germ cells can give rise to viable offspring via germline chimaeric chickens (Tajima et al., 1993; Naito et al., 1994c, 1998b). Avian primordial germ cells originate from the epiblast (Eyal-Giladi et al., 1981) and translocate to the hypoblast at stages XI-XIV (Eyal-Giladi and Kochav, 1976). The primordial germ cells are then carried anteriorly to the germinal crescent region. Finally, the cells migrate to the germinal ridges (the future gonads) via the blood vascular system and

Email:mnaito@affrc.go.jp differentiate into oogonia in female embryos and spermatogonia in male embryos (Nieuwkoop and Sutasurya, 1979; Kuwana, 1993).

An unincubated chicken blastoderm at stage $X$ is composed of a single layered area pellucida and a peripheral area opaca. The area pellucida is subdivided into a central disc and a peripheral marginal zone. Ginsburg and Eyal-Giladi (1987, 1989) and Ginsburg (1994, 1997) analysed the distribution of primordial germ cells and their precursors in stage $X$ blastoderm. They isolated and cultured various fragments of blastoderm in vitro and then determined the presence of primordial germ cells by periodic acid Schiff staining. These studies showed that most of the primordial germ cells originated from the central disc and not from the periphery of the area pellucida, and also indicated that primordial germ cells may be determined as early as stage X. Karagenc et al. (1996) and Petitte et al. (1997, 1999) investigated the origin of primordial germ cells in the prestreak stage of chicken embryos using monoclonal antibodies SSEA-1 and EMA-1, which recognize murine and chicken primordial germ cells, respectively (Hahnel and Eddy, 1986; Urven et al., 1988). They found 
that SSEA-1 and EMA-1 positive cells first appeared at stage $X$ on the ventral surface of the epiblast and later on the dorsal surface of the hypoblast. These SSEA-1 positive cells were proven to give rise to primordial germ cells by culturing them on feeder cells in vitro (Karagenc and Petitte, 2000). Kagami et al. (1997) also investigated the localization of the developmental origin of primordial germ cells in stage X blastoderm. These authors removed a cell cluster from various parts of the recipient blastoderm, injected donor blastodermal cells derived from whole blastoderm and examined the donor contribution to the recipient germline. When a cell cluster was removed from the centre of the central disc, donor-derived offspring were produced efficiently from the germline chimaeras. Kagami et al. (2000) performed a similar experiment by transferring donor cells obtained from various parts of stage $X$ blastoderm into recipient blastoderm and examined the number of primordial germ cells in the bloodstream of early recipient embryos. The number of primordial germ cells in the bloodstream was reduced by removing a cell cluster from the centre of the central disc of the stage X blastoderm, and the number recovered only when the blastodermal cells derived from the central disc were transferred into the stage $X$ recipient blastoderm. These authors concluded that primordial germ cells originate in the central part of the area pellucida and that the development of cells into primordial germ cells is determined at the stage $X$ blastoderm.

Germline chimaeric chickens were produced with high frequency by transfer of stage $X$ blastodermal cells derived from the area pellucida (Carsience et al., 1993; Kagami et al., 1995), which indicates that most germ cells arise from the area pellucida of the stage $X$ blastoderm. However, it has not been determined whether blastodermal cells derived from the marginal zone or area opaca can enter the germline of recipients and give rise to viable offspring.

The present study was performed to determine the distribution of primordial germ cells and their precursors in stage X blastoderm. Germline chimaeric chickens were produced by transfer of blastodermal cells derived from central disc, marginal zone or area opaca and the efficiency of production of donor-derived offspring from germline chimaeric chickens was examined. The ability of primordial germ cells and their precursors at stage $X$ to differentiate into functional gametes in the gonads of recipient embryos and chickens of the opposite sex was also examined.

\section{Materials and Methods}

\section{Fertilized eggs and animal care}

Fertilized eggs of White Leghorn and Barred Plymouth Rock chickens were obtained by artificial insemination from the genetic stocks maintained at the National Institute of Animal Industry. All animals received humane care as outlined in the Guide for the Care and Use of Experimental Animals (National Institute of Animal Industry Animal Care Committee).
Collection of stage $X$ blastoderm and separation into
central disc, marginal zone and area opaca

Unincubated fertilized Barred Plymouth Rock eggs were broken. The blastoderm was isolated from the yolk using a filter paper ring, placed in Dulbecco's PBS without $\mathrm{Ca}^{2+}$ or $\mathrm{Mg}^{2+}$ (No. 21300-025; Gibco BRL, Grand Island, NY) and separated into three portions (central disc and marginal zone of the area pellucida, and the area opaca) using plastic straws by pressing from above. Each portion of the blastoderm was dissociated by trypsin treatment $(0.25 \mathrm{~g}$ trypsin $\mathrm{I}^{-1}, 0.2 \mathrm{~g}^{\mathrm{EDTA}} \mathrm{I}^{-1}$; T4049, Sigma, St Louis, MO) at $37^{\circ} \mathrm{C}$ for $5 \mathrm{~min}$ and then dispersed in $\mathrm{KAv}-1$ medium (Minimum Essential Medium Alpha Medium ( $\alpha$-MEM No. 11900-024; Gibco BRL) supplemented with $1 \mathrm{mmol}$ Dglucose $\mathrm{I}^{-1}, 5 \times 10^{-5} \mathrm{~mol} 2$-mercaptoethanol $\mathrm{I}^{-1}, 10 \mathrm{mmol}$ $\mathrm{N}$-2-hydroxethylpiperazine- $\mathrm{N}^{\prime}$-3-propanesulphonic acid (EPPS) $\mathrm{I}^{-1}, 50 \mathrm{ml}$ fetal bovine serum $\mathrm{I}^{-1}, 50 \mathrm{ml}$ chicken serum $\mathrm{I}^{-1}$, pH 8.0 (Kuwana et al., 1996).

\section{Preparation of recipient embryos and injection of donor blastodermal cells}

Unincubated fertilized White Leghorn eggs were broken and the contents were put into glass vessels. The thick albumen was removed from the yolk and the blastoderm was placed on top of the yolk by rotating the yolk. A needle $(27 \mathrm{G} \times 3 / 4$; Terumo, Tokyo) connected to a micropipette was inserted underneath the blastoderm layer and a cell cluster containing about 700 cells was sucked from the centre of the central disc (Kagami et al., 1997; Naito et al., 1999). The cells collected were used for DNA extraction and sexing of recipient embryos. Donor blastodermal cells (500-1000 cells) derived from the central disc, marginal zone and area opaca were injected into the subgerminal cavity of the recipient embryos using a fine glass micropipette (Naito et al., 1991b). After injection, the residual cells of each blastoderm were used for DNA extraction and sexing of donor embryos. The manipulated embryos were transferred into host eggshells filled with thin albumen and sealed with cling film, plastic rings and elastic bands (Perry, 1988; Naito et al., 1990). The reconstituted eggs were incubated at $38^{\circ} \mathrm{C}$ and $60 \%$ relative humidity for 3 days in a forced air incubator (P-008B; Showa Incubator Laboratory, Yono-shi, Saitama). The embryos were then transferred into large host eggshells and incubated at $38^{\circ} \mathrm{C}$ and $60 \%$ relative humidity until hatching (Rowlett and Simkiss, 1987; Perry, 1988; Naito et al., 1990).

\section{Sex identification of donor blastodermal cells and recipient embryos}

DNA was extracted from the residual cells after injection of the donor blastodermal cells and from the blastodermal cells collected from the recipient embryos using a DNA extraction kit (SepaGene ${ }^{T M}$; Sanko Junyaku, Tokyo) according to the manufacturer's instructions. The extracted DNA was dissolved in $5 \mu \mathrm{l}$ Tris-EDTA (TE) buffer $(10 \mathrm{mmol}$ 
Table 1. Survival and hatching rates of manipulated chicken embryos

\begin{tabular}{lccc}
\hline $\begin{array}{l}\text { Portion of donor } \\
\text { blastoderm }\end{array}$ & $\begin{array}{c}\text { Number of eggs } \\
\text { manipulated }\end{array}$ & $\begin{array}{c}\text { Number (\%) of embryos } \\
\text { surviving at day } 3 \\
\text { of incubation }\end{array}$ & $\begin{array}{c}\text { Number (\%) } \\
\text { of chicks hatched }\end{array}$ \\
\hline Central disc & 724 & $395(54.6)$ & $58(8.0)$ \\
Marginal zone & 435 & $231(53.1)$ & $29(6.7)$ \\
Area opaca & 435 & $193(51.4)$ & $18(4.1)$ \\
Total & 1594 & $819(51.4)^{*}$ & $105(6.6)$ \\
\hline
\end{tabular}

*Twin embryos (178/819, 21.7\%) were included.

Tris- $-\mathrm{HCl} \mathrm{I}^{-1}, 0.25$ mmol EDTA I-1, $\mathrm{pH}$ 8.0). PCR analysis for sexing was carried out on the $1 \mu \mathrm{l}$ DNA samples (Naito et al., 1999). The reaction conditions and female specific DNA primers (5'-CCCAAATATAACACGCTTCACT- 3 ' and 5'-GAAATGAATTATTTTCTGGCGAC-3') for the PCR were performed according to the method of Clinton (1994) using a programmable thermal controller (Model 9700; Perkin Elmer, Foster City, CA). Control PCR reactions were also carried out to ensure the presence of genomic DNA using primers (5'-CAGATCAGTTTCTATCAGC- $3^{\prime}$ and $5^{\prime}$ TGTGACTTCAATGGTGACA- ${ }^{\prime}$ ) to amplify the chicken glyceraldehyde-3-phosphate dehydrogenase (GAPDH) gene (Clinton, 1994). After amplification, $5 \mu$ l aliquots of each reaction were combined, separated on a $2 \%(\mathrm{w} / \mathrm{v})$ agarose gel and visualized under UV irradiation after ethidium bromide staining. A band of 315 bp was detected in females but not males.

\section{Progeny test of putative chimaeric chickens}

For the autosomal pigment inhibitor gene, White Leghorn is homozygous dominant $(/ / /)$ and Barred Plymouth Rock is homozygous recessive $(i / i)$. Germline chimaerism of the putative chimaeric chickens produced by transfer of blastodermal cells (central disc, marginal zone or area opaca portion) from Barred Plymouth Rock to White Leghorn chickens was tested by mating with Barred Plymouth Rock chickens using artificial insemination, and the feather colour of their offspring was examined. Black offspring $(i / i)$ were derived from the donor blastodermal cells (Barred Plymouth Rock) and white offspring (I/i) were derived from the recipient embryos (White Leghorn).

\section{Analysis for the presence of the $W$ chromosome-specific repeating sequences in sperm samples}

Sperm samples were obtained from the male chimaeric chickens ( $n=15$ birds) produced by transfer of female blastodermal cells. DNA was extracted and dissolved in TE buffer. PCR analysis was carried out on 500 ng DNA samples to examine the presence of the $W$ chromosomespecific repeating sequences according to the method of Clinton (1994).

\section{Results \\ Survival and hatching rates of the manipulated embryos}

The survival rates of the manipulated embryos at day 3 of incubation were about $50 \%$ in any portion of the donor blastoderm transferred (Table 1). The average hatching rate was $6.6 \%(105 / 1594)$. The hatching rate was highest when blastodermal cells derived from the central disc were transferred and it was lowest when blastodermal cells derived from the area opaca were transferred. Twin embryos were sometimes observed $(21.7 \%, 178 / 819)$. Only one twin embryo developed to day 20 of incubation (just before hatching), but the others died by day 10 of incubation.

\section{Sex identification of donor blastodermal cells and recipient embryos}

The sexes of the donor blastodermal cells and recipient embryos were identified clearly by PCR. Each DNA sample was analysed twice and the same results were obtained in all samples. In all the recipient embryos, the sex identified by PCR was the same as the phenotypic sex of the hatched chickens.

\section{Chimaeric chickens and progeny tests}

Somatic and germline chimaeras were produced by transfer of Barred Plymouth Rock blastodermal cells to White Leghorn recipient embryos (Table 2). The percentages of feather pigmentation in the putative chimaeric chickens were variable $(0-90 \%)$. These percentages of feather pigmentation did not correlate with the germline chimaerism.

Sixty-one chickens were matured and test mated with Barred Plymouth Rock chickens; ten chickens proved to be germline chimaeras. The efficiency of producing germline chimaeric chickens was high when the blastodermal cells derived from the central disc were transferred into recipient embryos of the same sex; $50 \%$ (5/10) for males and $40 \%$ $(2 / 5)$ for females. In contrast, no germline chimaeric chickens were produced when blastodermal cells derived from the marginal zone or area opaca were transferred into recipient embryos of the same sex (0/12). Germline chimaeric chickens were also produced by transfer of blastodermal 
Table 2. Progeny test of chimaeric chickens produced by transfer of stage X blastodermal cells from Barred Plymouth Rock to White Leghorn chickens

\begin{tabular}{|c|c|c|c|c|c|c|c|}
\hline \multirow{2}{*}{$\begin{array}{l}\text { Portion of donor } \\
\text { blastoderm }\end{array}$} & \multicolumn{2}{|c|}{ Sex } & \multirow{2}{*}{$\begin{array}{c}\text { Number of birds } \\
\text { test mated }\end{array}$} & \multirow{2}{*}{$\begin{array}{c}\text { Mean percentage } \\
\text { of donor-derived } \\
\text { pigmentation (range) }\end{array}$} & \multirow{2}{*}{$\begin{array}{c}\text { Number (\%) } \\
\text { of germline } \\
\text { chimaeras (G0) }\end{array}$} & \multirow{2}{*}{$\begin{array}{l}\text { Mean number of } \\
\text { offspring (G1) } \\
\text { tested (range) }\end{array}$} & \multirow{2}{*}{$\begin{array}{l}\text { Percentage of } \\
\text { donor-derived } \\
\text { offspring (G1) }\end{array}$} \\
\hline & Donor & Recipient & & & & & \\
\hline Central disc & Male & Male & 10 & $12.0(0-70)$ & $5(50.0)$ & $248(40-583)$ & $0.65-4.68$ \\
\hline Marginal zone & Male & Male & 5 & $3.0(0-15)$ & 0 & $190(33-410)$ & - \\
\hline Area opaca & Male & Male & 4 & $4.0(0-20)$ & 0 & $158(16-324)$ & - \\
\hline Central disc & Female & Male & 9 & $4.4(0-20)$ & 0 & $241(10-409)$ & - \\
\hline Marginal zone & Female & Male & 3 & $0.0(-)$ & $1(33.3)$ & $178(37-328)$ & 0.58 \\
\hline Area opaca & Female & Male & 3 & $6.7(0-20)$ & 0 & $300(232-364)$ & - \\
\hline Central disc & Male & Female & 6 & $22.5(0-90)$ & $1(16.7)$ & $244(114-410)$ & 0.31 \\
\hline Marginal zone & Male & Female & 7 & $0.0(-)$ & 0 & $122(9-208)$ & - \\
\hline Area opaca & Male & Female & 6 & $13.3(0-80)$ & $1(16.7)$ & $172(14-418)$ & 0.49 \\
\hline Central disc & Female & Female & 5 & $5.0(0-10)$ & $2(40.0)$ & $160(50-233)$ & $0.43-1.28$ \\
\hline Marginal zone & Female & Female & 1 & $0.0(-)$ & 0 & $320(-)$ & - \\
\hline Area opaca & Female & Female & 2 & $0.0(-)$ & 0 & $135(87-182)$ & - \\
\hline
\end{tabular}

cells derived from the central disc $(6.7 \%, 1 / 15)$, marginal zone $(10.0 \%, 1 / 10)$ or area opaca $(11.1 \%, 1 / 9)$ into recipient embryos of the opposite sex.

Both male and female donor-derived offspring were produced from same sex and mixed sex germline chimaeric chickens and the reproductive performance of these donorderived offspring was normal.

\section{Analysis for the presence of the $W$ chromosome-specific repeating sequences in the sperm samples}

W chromosome-specific repeating sequences were not detected in any of the DNA samples by PCR analysis, probably due to the low contribution of donor-derived germ cells in recipient gonads.

\section{Discussion}

In this study, stage $X$ blastodermal cells derived from the central disc, marginal zone or area opaca were transferred into recipient embryos of the same developmental stage from which a cell cluster was removed from the centre of the central disc. The putative chimaeric chickens produced were test mated to examine the germline chimaerism. Germline chimaeric chickens were produced efficiently $(46.7 \%, 7 / 15)$ when blastodermal cells derived from the central disc were transferred into recipient embryos of the same sex, whereas no germline chimaeric chickens were produced when blastodermal cells derived from the marginal zone or area opaca were transferred into the recipient embryos of the same-sex (0/12). Germline chimaeric chickens were also produced by transfer of blastodermal cells derived from the central disc, marginal zone or area opaca into the recipient embryos of the opposite sex. These results indicate that the development of the germline is not limited to the cells from the central disc of the area pellucida and that the cells from other regions (marginal zone or area opaca) can give rise to germ cells, although the frequency is low.

Ginsburg (1994) examined the distribution of primordial germ cells or their precursors in stage $X$ blastoderm by counting the number of primordial germ cells after culturing various portions (central disc, marginal zone, area pellucida or dissected pieces of central disc) of the blastoderm, and estimated that $90.2 \%$ of primordial germ cells arise from the central disc, $9.7 \%$ from the marginal zone and $0.1 \%$ from the area opaca. Ginsburg (1994) also demonstrated that the main population of primordial germ cells arises from the centre of the central disc. Kagami et al. (1997, 2000) showed that removal of a cell cluster from the centre of the central disc of stage $X$ blastoderm followed by injection of donor blastodermal cells derived from the central disc fully recovered the number of primordial germ cells in the bloodstream of recipient embryos. Taken together, these results indicate that primordial germ cells seem to be determined during or shortly after stage $X$ and that while most primordial germ cells or their precursors locate in the central part of the area pellucida of the stage X blastoderm, some locate in the marginal zone or area opaca.

Many genes are involved in the determination of germline and, of these, the vasa gene plays an essential role in germline formation in Drosophila (Liang et al., 1994). Expression of the vasa gene is not transient but persists throughout the germline; therefore, germline formation and germ cell movement can be traced by analysing the expression of the vasa gene. Tsunekawa et al. (2000) isolated the chicken homologue to the vasa gene and examined the germline-specific expression of the chicken vasa homologue $(\mathrm{CVH})$ protein. $\mathrm{CVH}$ protein was localized in the cytoplasm of germ cells ranging from presumptive 
primordial germ cells in uterine stage embryos to spermatids and oocytes in adult gonads. At stage $X$ blastoderm, about $30 \mathrm{CVH}$ expressing cells were scattered in the central part of the area pellucida. The subsequent movement of $\mathrm{CVH}$-positive cells was in accordance with the cells recognized by SSEA-1 and EMA-1, or periodic acid Schiff staining. The results of the distribution of $\mathrm{CVH}$ positive cells strongly support the contention that most primordial germ cells in stage $\mathrm{X}$ blastoderm are located in the central part of the area pellucida. Furthermore, $\mathrm{CVH}$ protein was predominantly localized in oocytes. The $\mathrm{CVH}$ containing cytoplasmic structure seems to be the precursory germ plasm, indicating that chicken germline is determined by maternally inherited factors in the germ plasm (Tsunekawa et al., 2000).

In the present study, same sex and mixed sex germline chimaeric chickens were produced by transfer of stage $X$ blastodermal cells as described by Kagami et al. (1995, 1997). The production of donor-derived offspring from mixed sex germline chimaeric chickens indicates that primordial germ cells at stage $X$ have the ability to differentiate normally into both male and female gametes irrespective of their genetic sex. However, this ability is lost rapidly during the first 2-3 days of incubation, as few donor-derived offspring were produced from the mixed-sex germline chimaeric chickens produced by transfer of primordial germ cells isolated from the blood of embryos incubated for 2.5 days (Naito et al., 1999).

Sexual differentiation in chickens starts at days 5-7 of incubation (Mizuno et al., 1993), at the time the aromatase gene is expressed specifically in female embryos. The primary differentiation of primordial germ cells takes place by day 3 of incubation, either actively or passively, as the number of primordial germ cells in the bloodstream of embryos incubated for 2 days is greater in females than in males (Naito et al., 1999). Raymond et al. (1999) reported that the chicken Dmrt1 gene (Z-linked) is expressed in the genital ridge and Wolffian duct before sexual differentiation and that expression is higher in male embryos than in female embryos. The Dmrt1 gene is expressed in mouse primordial germ cells as well as Sertoli cells, indicating that the gene may play a role in the development or function of germline. As the expression of the Dmrt1 gene in early chicken embryos by day 3 of incubation has not been examined, the primary differentiation of primordial germ cells before sexual differentiation and the expression of the Dmrt1 gene in the early chicken embryos should be examined.

In conclusion, the results of the present study indicate that primordial germ cells are induced during or shortly after stage $X$ and confirm that cells derived from the central disc have the highest potential to give rise to germ cells and that cells derived from the marginal zone and area opaca can also give rise to germ cells, although the frequency is low.

The authors would like to thank the staff of the Poultry Management Section of the National Institute of Animal Industry for taking care of the birds. This study was supported by the Special Coordination Fund for Promoting Science and Technology from the Science and Technology Agency of the Japanese Government. A part of this study was carried out by the Cooperative System for Supporting Priority Research.

\section{References}

Carsience RS, Clark ME, Verrinder Gibbins AM and Etches RJ (1993) Germline chimeric chickens from dispersed donor blastodermal cells and compromised recipient embryos Development 117 669-675

Clinton M (1994) A rapid protocol for sexing chick embryos (Gallus $g$. domesticus). Animal Genetics 25 361-362

Eyal-Giladi H and Kochav S (1976) From cleavage to primitive streak formation: a complementary normal table and a new look at the first stages of the development of the chick I. General morphology Developmental Biology 49 321-337

Eyal-Giladi H, Ginsburg M and Fabarof A (1981) Avian primordial germ cells are of epiblastic origin Journal of Embryology and Experimental Morphology 65 139-147

Ginsburg M (1994) Primordial germ cell formation in birds. In Germline Development: Ciba Foundation Symposium 182 pp 52-67 Eds J Marsh and J Goode. John Wiley and Sons, Chichester

Ginsburg M (1997) Primordial germ cell development in avians Poultry Science 76 91-95

Ginsburg M and Eyal-Giladi H (1987) Primordial germ cells of the young chick blastoderm originate from the central zone of the area pellucida irrespective of the embryo-forming process Development 101 209-219

Ginsburg M and Eyal-Giladi H (1989) Primordial germ cell development in cultures of dispersed central disks of stage X chick blastoderms Gamete Research 23 421-427

Hahnel AC and Eddy EM (1986) Cell surface markers of mouse primordial germ cells defined by two monoclonal antibodies Gamete Research 15 25-34

Kagami H, Clark ME, Verrinder Gibbins AM and Etches RJ (1995) Sexual differentiation of chimeric chickens containing ZZ and ZW cells in the germline Molecular Reproduction and Development 42 379-387

Kagami H, Tagami T, Matsubara Y, Harumi T, Hanada H, Maruyama K, Sakurai M, Kuwana T and Naito M (1997) The developmental origin of primordial germ cells and the transmission of the donor-derived gametes in mixed-sex germline chimeras to the offspring in the chicken Molecular Reproduction and Development 48 501-510

Kagami H, Iwata J, Nakata A et al. (2000) Substantial evidence to localize the developmental origin of primordial germ cells in the chicken Animal Science Journal 71 38-41

Karagenc L and Petitte JN (2000) Soluble factors and the emergence of chick primordial germ cells in vitro. Poultry Science 79 80-85

Karagenc L, Cinnamon Y, Ginsburg M and Petitte JN (1996) Origin of primordial germ cells in the prestreak chick embryo Developmental Genetics 19 290-301

Kuwana T (1993) Migration of avian primordial germ cells toward the gonadal anlarge Development Growth and Differentiation 35 237-243

Kuwana T, Hashimoto K, Nakanishi A, Yasuda Y, Tajima A and Naito M (1996) Long-term culture of avian embryonic cells in vitro. International Journal of Developmental Biology 40 1061-1064

Liang L, Diehl-Jones W and Lasko P (1994) Localization of vasa protein to the Drosophila pole plasm is independent of its RNA-binding and helicase activities Development 120 1201-1211

Mizuno S, Saitoh Y, Nomura O, Kunita R, Ohtomo K, Nishimori K, Ono H and Saitoh H (1993) Sex-specific DNA sequence in Galliformes and their application to the study of sex differentiation. In Manipulation of the Avian Genome pp 257-274 Eds RJ Etches and AM Verrinder Gibbins. CRC Press, Boca Raton

Naito M (1997) The microinjection of DNA into early chicken embryo. In Transgenic Animals: Generation and Use pp 69-73 Ed. LM Houdebine. Harwood Academic Publishers, Amsterdam

Naito M (1998) Manipulation of primordial germ cells for avian transgenesis AgBiotech News and Information 10 397-404 
Naito M, Nirasawa K and Oishi T (1990) Development in culture of the chick embryo from fertilized ovum to hatching Journal of Experimental Zoology 254 322-326

Naito M, Agata K, Otsuka K, Kino K, Ohta M, Hirose K, Perry MM and Eguchi G (1991a) Embryonic expression of $\beta$-actin-lac $Z$ hybrid gene injected into the fertilized ovum of the domestic fowl International Journal of Developmental Biology 35 69-75

Naito M, Watanabe M, Kinutani M, Nirasawa K and Oishi T (1991b) Production of quail-chick chimaeras by blastoderm cell transfer British Poultry Science 32 79-86

Naito M, Sasaki E, Ohtaki M and Sakurai M (1994a) Introduction of exogenous DNA into somatic and germ cells of chickens by microinjection into the germinal disc of fertilized ova Molecular Reproduction and Development 37 167-171

Naito M, Tajima A, Tagami T, Yasuda Y and Kuwana T (1994b) Preservation of chick primordial germ cells in liquid nitrogen and subsequent production of viable offspring Journal of Reproduction and Fertility 102 321-325

Naito M, Tajima A, Yasuda Y and Kuwana T (1994c) Production of germline chimeric chickens, with high transmission rate of donor-derived gametes, produced by transfer of primordial germ cells Molecular Reproduction and Development 39 153-161

Naito M, Sakurai M and Kuwana T (1998a) Expression of exogenous DNA in the gonads of chimaeric chicken embryos produced by transfer of primordial germ cells transfected in vitro and subsequent fate of the introduced DNA Journal of Reproduction and Fertility 113 137-143

Naito M, Tajima A, Yasuda Y and Kuwana T (1998b) Donor primordial germ cell-derived offspring from recipient germline chimaeric chickens: absence of long term immune rejection and effects on sex ratios British Poultry Science 39 20-23

Naito M, Matsubara Y, Harumi T, Tagami T, Kagami H, Sakurai M and Kuwana T (1999) Differentiation of donor primordial germ cells into functional gametes in the gonads of mixed-sex germline chimaeric chickens produced by transfer of primordial germ cells isolated from embryonic blood Journal of Reproduction and Fertility 117 291-298

Naito M, Matsubara Y, Harumi T, Tagami T, Sakurai M and Kuwana T (2000a) Foreign gene expression in the gonads of chimaeric chicken embryos by transfer of primordial germ cells transfected in vitro by lipofection for 24 hours Animal Science Journal 71 308-311

Naito M, Sano A, Tagami T, Harumi T and Matsubara Y (2000b) Efficient transfection of chicken blastoderms in vivo by lipofection and electroporation using green fluorescent protein gene as a marker Animal Science Journal 71 377-385

Nieuwkoop PD and Sutasurya LA (1979) Primordial germ cells in the Chordates Cambridge University Press, Cambridge
Perry MM (1988) A complete culture system for the chick embryo Nature $33170-72$

Petitte JN, Karagenc L and Ginsburg M (1997) The origin of the avian germ line and transgenesis in birds Poultry Science 76 1084-1092

Petitte JN, D'Costa S and Karagenc L (1999) Understanding the origin of avian primordial germ cells: implications for germ cell culture and transgenesis in poultry. In Transgenic Animals in Agriculture pp 97-116 Eds JD Murray, GB Anderson, AM Oberbauer and MM McGloughlin. CABI Publishing, Cambridge

Raymond CS, Kettlewell JR, Hirsch B, Bardwell VJ and Zarkower D (1999) Expression of Dmrt1 in the genital ridge of mouse and chicken embryos suggests a role in vertebrate sexual development Developmental Biology 215 208-220

Rowlett K and Simkiss K (1987) Explanted embryo culture: in vitro and in ovo techniques for domestic fowl British Poultry Science 28 91-101

Tajima A, Naito M, Yasuda Y and Kuwana T (1993) Production of germ line chimera by transfer of primordial germ cells in domestic chicken (Gallus domesticus) Theriogenology 40 509-519

Tajima A, Naito M, Yasuda Y and Kuwana T (1998) Production of germ-line chimeras by transfer of cryopreserved gonadal primordial germ cells (gPGCs) in chicken Journal of Experimental Zoology 280 265-267

Tsunekawa N, Naito M, Sakai Y, Nishida T and Noce T (2000) Isolation of chicken vasa homologue gene and tracing the origin of primordial germ cells Development 127 2741-2750

Wentworth B, Tsai H, Wentworth A, Wong E, Proudman J and El Halawani M (1996) Primordial germ cells for genetic modification of Poultry. In Biotechnology's Role in the Genetic Improvement of Farm Animals pp 202-227 Eds RH Miller, VG Pursel and HD Norman. American Society of Animal Science, Savoy

Wong EA, Wentworth AL, Wentworth BC, Proudman JA and El Halawani ME (1999) Generation of transgenic poultry by transfection of primordial germ cells. In Transgenic Animals in Agriculture pp 117-129 Eds JD Murray, GB Anderson, AM Oberbauer and MM McGloughlin. CABI, Oxon

Urven LE, Erickson CA, Abbott UK and McCarrey JR (1988) Analysis of germ line development in the chick using anti-mouse EC cell antibody Development 103 299-304

Received 10 August 2000.

First decision 27 September 2000.

Accepted 5 December 2000. 